\title{
A Brief Account Of Banking History: From Erstwhile Babylon To Present Day Kashmir
}

\author{
Faheem Iqbal Shayiq ${ }^{1}$ \\ Associate Executive (Legal), J\&K Bank \\ (B.Sc, M.A (Eng) LL.M, N.E.T, Currently pursuing Ph.D. Law)
}

\begin{abstract}
The activity of banking has traversed an impeccable journey since its inception, usually traced to the erstwhile Babylon, a period during which the Priests wielded tremendous authority \& power, quite naturally they used the religious institutions as the safe places to carry out the earliest forms of banking transactions. The banking business received impetus with the growth of trade \& economy throughout the globe. As such banking as is understood in the contemporary society started receiving acceptance in masses \& this prompted measures for its proper regulation. Following the trend, India also started active pursuit to reform \& redefine the activity which was carried out since the period of Vedas. The present author has made an effort to briefly trace the history of banking throughout world including India \& the State of Jammu \& Kashmir. The paper also attempts to decipher the barriers which come in the way of reform \& development in the current context.
\end{abstract}

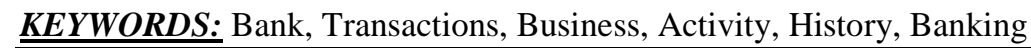

\section{1. WORD ORIGIN}

The genesis of the word 'bank' can be traced to old high Germanic word 'banc', by eminent historians $\&$ linguists. The 'banc' referred to benches or counters which were used as makeshift desks for carrying out transactions of the earliest form. In Italy this word 'banc' progressively took the form of 'banca' or 'bonco'. In due course of time, French linguists used 'banque' to refer to the similar forms of transactions. During these times, the failure of the business was marked by breaking the table on which these transactions were carried out $\&$ as such gave birth to the word 'bankrupt', breaking/rupturing the bench. The content \&meaning of the term remained majorly same in those times despite undergoing change in its form. There is yet another line of thought wherein linguists \&historians of Iran strongly contend that 'bank' comes from ancient Persian word 'Ban gah' or 'bon gah'. 'Ban' or 'bon' meant 'fund' while as 'gah' was understood as a 'location', 'place' or 'enclosed area'. The word bongah is still in prevalence in modern Persian language. In England during the 'middle phase' of growth of English language, the word 'bank' in its current form came to be used for the first time, changing from bench to bank.

GERMANIC(Old-Norse)-banc-ITALIAN—banco-FRENCH—banque—ENGLISH-bench--bank

\section{BANKING AS A BUSINESS \& ACTIVITY: A GLOBAL RETROSPECT}

There is almost unison in the thought that the earliest forms of banking, as is understood in its common parlance, started in the Semitic kingdoms of Assyria \& Babylonia. These monarchies supposedly had progressive work culture \& sense of business. The transcripts in the form of clay tablets dating back to 2000 B.C.,reveal the same. The Babylonians used to deposit their personal belongings \& jewelry for safe keeping. In return of this service of safe keeping, would charge $1 / 60^{\text {th }}$ of net worth of the entrusted good or article. There was a regulation in place known as 'the Hammurabi's codes', regarded as the oldest forms of codified laws. With the development of the concept of banking,in Rome \& Greece, during the reigns of Roman Empire, influential people started lending \& advancing loans by making some innovations like accepting deposits \&money changing. As incredible \& strange as it may sound, temples consecrated to ancient gods were the first banks in Rome \& Greece. In ancient Greece, around2000 B.C. the famous temple of Epesus, Delphi and Olympia were used as depositories for peoples surplus funds and these temples were the centers of money lending

1

Faheem Iqbal Shayiq, (B.Sc, M.A (Eng), LL.M, N.E.T), Associate Executive (Legal), Chairman's Secretariat, J\&K Bank Ltd., Pursuing Part-time Ph.D. (Law), Kashmir University

DOI: $10.9790 / 0837-2203025969 \quad$ www.iosrjournals.org $\quad 59 \mid$ Page


transactions. The priests during this era wielded tremendous authority, power \& respect \& anything they said was considered as law. The priests started

accepting deposits in the form of money, treasure, jewelry etc. for safe custody. So priests were the foremost bankers in Roman kingdom. The practice receivedhuge popularity \& soon became a complex business activity. To cater to the developing system, the business was moved out in the open. Roman authorities, as such, set offices in a row on the north side of the forum on the 'Street of Janus'. This street can be considered as the Wall Street of those times, as a forum for money changers. This locality named on the double-faced god, Janus, revered in Roman mythology, is known to be frequented by bankers (of that era) \& money changers. ${ }^{2}$ These bankers \& money changers would bring \& sell foreign coins of various denominations, accept deposits, advance loans \& issue bills of exchange besides buy mortgages. The prosperous trade \& business of the Roman Empire (Pax Romana) was because of certain favorable conditions like skilled specialized labor force able to produce excellent but cheap goods, a sophisticated network of transportation and trade to move and distribute goods. Besides this an eminent Imperial government that minted enough coins and maintained the roads to sustain the economy ${ }^{3}$. Though a retrogressive practice, prevalent in early Rome, as in Greece, was slavery. Slavery for debt was permitted under the law. In 450 B.C. for instance, the 'Twelve Tables of Rome' leges duodecim tabularum or duodecim tabulae (yet another prominent codified laws of the earliest times),provided that a debtor might pay the borrowed money within thirty days following a judgement to the merits of the case, failing which his person might be seized by his creditors. A father was also permitted to sell his son into slavery in liquidation of the debt. This practice can be considered as one of tyrannical inhuman practices which reduced human to chattel $\&$ commodities. The worst part of the story was that such practices had the backing of law of the land. The laws were mostly based on 'positus' lacking the elements of morality. But due to efforts \& theories of various philosophers in due course of time, the law to be considered 'law' was to conform to the higher law i.e, the 'Natural law'. But during the period under consideration the laws were bereft of morality and the 'ought to' element in law was missing. However there was a trivial safeguard under the law, which forbade repetition of the practice thrice. After the father did the same for the third time, the son was released from paternal control. ${ }^{4}$ 
In the $6^{\text {th }}$ Century B.C, the Justinian code, a reviewed 'corpus juris civilis' (civil law), although it didn't strictly speaking constitute a new code, under the Byzantine emperor provided for regulation in lending \& trading in moneys. But with the fall from grace of the great Roman Empire, trade slumped \& declined sharply, consequent of which the banks also slowly but steadily vanished from the scene. In the medieval period, the first bank known as 'Bank of Venice' was established in Italy in $1157^{5}$. The banking saw a fresh lease of life \& started reviving as an institution during the $12^{\text {th }} \& 13^{\text {th }}$ centuries. During this era, the towns of Italy, Florence \& Genoa took a lead. During the medieval \& Renaissance Italy, the 'Bardi' \& 'Peruzi' families dominated the scene in the $14^{\text {th }}$ century 'Florence' \& they established branches in many other parts of Europe. Yet another business family deserving mention was the 'House of Medici', an Italian banking family that began to thrive under Cosimo de' Medici, who was an Italian banker \& politician, later considered as the Father of Nation (pater patriae) in the Republic of Florence during first half of $15^{\text {th }}$ century, gradually rising until they were able to fund the 'Medici Bank'. This bank over a period of time became the most prosperous \& respected institutions in Europe. ${ }^{6}$ In Genoa, perhaps, banking most nearly approached a public function through the famous Bank of Saint Georgia.So firmly it was established, so sagaciously it was directed, and so tenaciously jealous of its privileges that it was able to function continuously through seven centuries. ${ }^{7}$ In the $16^{\text {th }}$ Century, a German business

family, called the "Fuggers" from Ausberg became important financers \& Bankers. The Fuggers were the wealthiest merchant family of the $16^{\text {th }}$ century Germany with extensive business activities in finance $\&$ overseas ventures, making it a truly global enterprise at the beginning of modern age. In the $17^{\text {th }}$ century, a courtJew, Mayor Rothschild established \& extended his banking empire across Europe, carefully placing all five sons in key positions in the business start-up.This family, by the mid 1800, dominated the banking industry, and started lending even governments of the day, opening bank branches in Frankfurt, Vienna,London and Paris notably.

As per Mohammad Naveed, Islamic Banking, a completely different \& innovative method of financing prevailed \& was practiced far more early than commonly understood. Islamic Banking is as old as the religion itself, with the principles primarily derived from the holy scripture, Quran. ${ }^{8}$ Some principles of Islamic finance have been adopted \& incorporated into modern conventional banking products such as letters of credit and cheques. The products are based on permitted activities as laid down in the Quranic verses. The permissible practices \& injunctions include prohibition of Riba (interest) at the first place, moral \& ethical Considerations while dealing in business (justifiable profiteering) like the present day legislations 'Prohibition of Unfair Trade Practices' to quote one in the instant case, charity (corporate social responsibility in the present era), wealth accumulation principles as well as communal development. During the Golden age of Islamic Civilization, which can be traced from the $7^{\text {th }}$ to $13^{\text {th }}$ centuries possibly, though the same age is usually referred by Europeans as the dark ages, presumably due to the little growth within the Christian community as compared to Muslims in that era, since Muslims in this era conquered many lands and established their reigns. The early Muslims engaged in transactions based on Shariah (Islamic Jurisprudence), \& Islamic economic principles. During this era, the inhabitants established trade routes which stretched from Gibralter (Jabal al Tariq in Arabic) to the sea of China along which flowed trade based on principles of Islamic commerce. An early market economy and an early form of mercantilism was developed between $8^{\text {th }} \& 12^{\text {th }}$ centuries. ${ }^{9}$ The monetary economy of this period was based on widely circulated currency, the gold Dinar, which was an Islamic medieval gold coin first issued by theUmmayad caliphate, a regime founded by Muwaiya ibn Sufiyan, long term governor of Syria and which at its prime ruled $29 \%$ of the total world population with a georaphical stretch of $4,300,000 \mathrm{sq} \mathrm{miles}{ }^{10}$, making it one of the largest empires in the history.Under the dynasties that followed, the use of Dinar spread from Islamic Spain to Central Asia. However the first dated coins, made of silver (silver Dirhams) can beascribed to the Sassanian Empire of Iran, which was the last Imperial dynasty in Iran, before the rise of Islam, introduced by its ruler Yezdegard III (aZoroastrian), later run over by Islamic armies, struck in the Uthman (Usman) Caliphate. A number of economic concepts \& techniques were applied in earlyIslamic banking, including bills of exchange, partnership (mudaraba), and forms of capital (al-mal), capital accumulation (nama al-mal), ${ }^{11}$ cheques, promissory notes ${ }^{12}$. Muslim Traders are known to have used cheques or 'sakk system' since the time of Harun Rashid as early as in $9^{\text {th }}$ century of the Abassid Caliphate ${ }^{13}$,trusts (Waqf) ${ }^{14}$, transactional accounts, loaning,

\footnotetext{
5 Dr. Rega Surya Rao, Lectures on Banking Law, Andhra Law House, p 3

House of Medici, from Wikipedia www.wikipedia.org

Supra note 1 , page 64

Mohammad Naveed, A History of Islamic Finance, Islamic Finance, www.islamicfinance.com

Subhi Y. Labib, Capitalism in Medieval Islam, The Journal of Economics, 1969 p 79-96(81,83,85,90,93,96)

Umayyad Caliphate, from Wikipedia, www.wikipedia.org

Jairus Banaji, 2007, Islam, The Mediteranean \& Rise of Capitalism, Historical Materialism, p 47-74 Brill Publishers

Robert Sabatiano Lopez, Irving Woodworth Raymond, Olivia Remie Constable, Medieval Trade in the Meditareanean world, Illustrate Documents, Columbia university press, 2001

13 Glubb, John Bagot, A short History of Arab Peoples, Dorset Press, 1988 p 105
}

DOI: 10.9790/0837-2106010106 www.iosrjournals.org $61 \mid$ Page 
ledgers and assignments ${ }^{15}$.It won't be out of place to mention here that Harun Rashid was a charismatic leader \& practiced Islamic belief with stringency which of course were based onJustice \& fairness. The business dealings in his period were supposed to conform to moral principles, which ought not to be in conflict with the societal interests. Cannot the social control be carried on and achieve its purpose without lawyers law, i.e., without an elaborate body of authoritative grounds of or grounds to decision? Conceivably it can. There may be administration of justice by the unguided, unchecked will of a ruler or of a magistrate. Such was the justice of Harun Rashid. ${ }^{16}$ Organizational enterprises independent from the state also existed in the medieval Islamic world, while the agency institution was also introduced during that time. Many of these political banking concepts were adopted and further advanced in medieval Europe from the $13^{\text {th }}$ century onwards. ${ }^{17}$ In England the banking system started to develop in the $17^{\text {th }}$ century, considered as the modern era of banking Business. The merchants of England started to store Gold with 'English Goldsmiths' who possessed private vaults \& charged a fee for that service. Receipts used to be issued against the deposit, certifying the title. Gradually the Goldsmiths instead of receipts started lending money in exchange to the deposited metal. The 'promissory notes' evolved into 'bank notes' over a period of time, were issued as a valid instrument for business convenience. ${ }^{18}$. However Goldsmiths suffered a serious setback during the reign of King Charles II,who issued a directive that no payments should be made to goldsmiths. As a result the banking business by goldsmiths disappeared in due course of time and paved a way for the emergence of modern banking system. ${ }^{19}$ The stoppage of payments due to the Goldsmiths referred to as the 'Great stop of 1672', busted the Goldsmiths business big time \& consequently five leading dealers went bankrupt. The changes brought about by wars like the one fought with France in $17^{\text {th }}$ century, compelled government to borrow so as to come out of crisis situation. As a consequence, the Bank of England, also known as lady of Threadneedle Street was founded in 1694 by a Royal Charter, following the glorious revolution of 1688 . It will be interesting to shed a bit of light on the background of the name 'Lady of Threadneedle'. The question, 'was there an old lady of Threadneedle street and what she had to do with banking?' needs to be answered. There was indeed an old lady..Sarah whitehead. Sarah had a brother called Philip, a disgruntled employee, who was found guilty of forgery in 1811, and executed for his crime. Poor Sarah was so shocked she became 'unhinged' and every day for the next 25 years she went to the Bank and asked to see her brother. When she died, she was buried in the old churchyard that later became the bank's garden, and her ghost is believed to have been seen on many occasions in the past. ${ }^{20}$ The Royal Charter in 1694 culminated in 'The Tonnage Act' or 'The Bank of England Act, 1694. The Act authorized the raising of capital to the tune of Pound1,20,000 by way of subscriptions besides authorizing the formation of a body corporate which composed of the subscribers as 'The Governor \& Company of the Bank of England'. The corporation so formed was to lend the whole of its capital to the government \& was forbidden to carry on any other trade. Initially the charter licensed the corporation to carry on banking business for a period of 12 years subject to a review, on which the government could annul the charter after 1years notice was served to the said corporation. This was only the second oldest Central bank in the world after Swedish Riksbank. The need for a central bank in England was seen by Scotsman, William Patterson, who noticed the nation's finances were in complete disarray after the wars, largely ascribed to the miseries on William III brought about by the French war. To undo the English National debt, a 'private company' solely formed \& funded by private subscription saw instant success, riding on an initiative taken by financers, who joined together to set up the bank, getting incorporated as the 'Governor and company' of the Bank ofEngland. The bank then loaned the government a Pound 1.2 Million (a massive sum in those days). The bank in return would seek an interest at the rate of $8 \%$ and the right to issue notes. Bank of England as such became the first to issue banknotes in a permanent form in 1695. At the end of world war II, the bank became aBritish Public Institution in 1946 \& was nationalized by Atlee government. During this period developments in banking business were visibly taking place elsewhere in the world at the same time. Bank of Amsterdam was established in Holland, in the year 1609. In the year 1619, another bank, Bank of Heimberg was established in Germany ${ }^{21}$, which hinted at the development of banking system as a global phenomenon. A trend of establishing central banks developed during this period. In this context, the Swedish 'Riksbank' came to be established which is known to be the oldest Central bank in the

Timur Kuran, The absence of Corporation in Islamic Law, Origins and persistence, American Journal of comparative law 200553 , p 785-834, 798-9

Subi Y.labib, The Law, agency, and policy in Medieval Islamic Society,: Development of the institutions of Learning from the tenth to the fifteenth century, comparative Studies in Society \& History ,1969 41, pp 263-93, Cambridge University Press

Rosco Pound, Justice According to Law, Yale University Press, New Haven, 1951 P 32

Ibid 5

Wikipedia en.wikipedia.org

Dr. Rega Surya Rao, Lectures on Law of Banking, Andhra Law House, p2

Ellen Castelow, The Old lady of Threadneedle Street, Historic UK, www.historic-uk.com

Dutta's Banking Law, R.Dutta, R.P Shukla, Dwivedi Law Agency, 2010 (Lectures on Banking Law, Anjani Kant,CLP) 
world. In 1668 Johan Palmstruch, the founder of Sweden's first bank, Stockholmes Banco, implemented his novious idea of facilitating the management of money by beginning to issue the first real currency notes. Interestingly the bank had 20 employees in the beginning, who were all men. This bank issued printed notes known as Palmstruchare in year 1666 with denominations of 5,25,50 \& $100 .{ }^{22}$ In 1778 , 'Royal Bank of Scotland', yet another noteworthy institution in those days, invented the concept of 'overdraft', a modern day practice in banks, wherein the account holder with a worthy bank dealing utilizes money more than what is actually available to his credit in his account \& which is then repaid along with interest after his account gets credited by an income. The Royal Bank of Scotland, in the instant case, allowed William Hog, a merchant, to take Pound 1000 more out of his account than he had in it. ${ }^{23}$ In those times bank accounts were few \& were considered a luxury for the rich. Noteworthy to mention that overdraft facility in those times could be seen as a great innovation in terms of allowing over drawings from one's account in special circumstances. The Modern day banking began in England with the Bank Charter Act of 1844. The Act split the Bank of England (which continued to be a private bank by then into two departments-a banking department and an issuing department. Until the mid-nineteenth century, commercial banks in Britain \& Ireland were able to issue their own bank notes. The Charter Act forbade all other banks to issue bank notes \& as such the Bank of England had the authority to issue notes exclusively. The Bank of England was finally nationalized in the year 1946. The first cash dispensing machine was however installed by one of the reputed banks of England 'Barclays Bank' at one of it Branches in Enfield, London in the year 1967, which could be seen as a major breakthrough in banking technology \& innovation.

\section{BANKING AS A BUSSINESS \& ACTIVITY: A NATIONAL RETROSPECT}

It may be stated that modern Indian banking law is based to a very large extent, though not entirely, upon the English Banking Law ${ }^{24}$, as such the developments

may be seen in the light of developments of Banking law in England. The entire banking since time immemorial in India was carried out by money lenders, who

would lend money to needy \& in return seek exorbitant interest. These indigenous money lenders were referred by different names like Seth', Sahukar, Sarraf etc.

While word 'seth' would mean well-off, royal, the rich or merchants of repute, Sahukar symbolized honesty, credibility \& integrity, which is a modern notion of banking i.e., based on trust.

The institution of banking in its primitive form is believed to be in existence in India as early as during the Vedic Period, drawing authority from the earlier texts

'Vedas'. During the Smriti Period, banking was carried by people of 'Vaish' community by accepting deposits $\&$ granting advances. Hindu religious texts assigned Vaishyas to traditional roles of cattle rearing and agriculture but over a period of time they came to be landowners, traders and money lenders. ${ }^{25}$ Drawing authority from the Smritis, believed to be compiled between 600\& 200BC., Guatama, Vrihaspati, Yajnavlkya, Prasara, etc., explained the methods of regulation of interest in their Smritis. ${ }^{26}$ However during the Buddhist period it saw a decline as Buddha \& Mahavira considered money lending a sin \& denounced it. ${ }^{27}$ Similarly in Kautilya's Arthashastra, written in the Mauryan period of $4^{\text {th }}$ century BC, has mentioned about the maximum rate of interest that could be charged by the money lenders. The bankers during this period were known as Sahukars \& Mahajans. ${ }^{28}$ During the Mughal period, Indigenous banking was at its prime. There washardly a village without a money-lender or Saraf, who financed trade \& commerce. The rulers at that time also depended on these money lenders \& appointedthem as revenue collectors. The use of Hundi (Bills of exchange as understood in the modern parlance), prevailed greatly during the Mughal regime. In fact theHundi network was so widespread throughout the Empire \& was customizable according to need. For example a trader depositing money at one part ofthe kingdom with a banker received Hundi which would entitle him to encash it anywhere in other part of the kingdom. These Hundis were issued by bankers(Sarafs) appointed for this matter in the course of business. Besides they also dealt in coinage 'sicca' of the Mughal rule. Allegedly there was a practice of creating

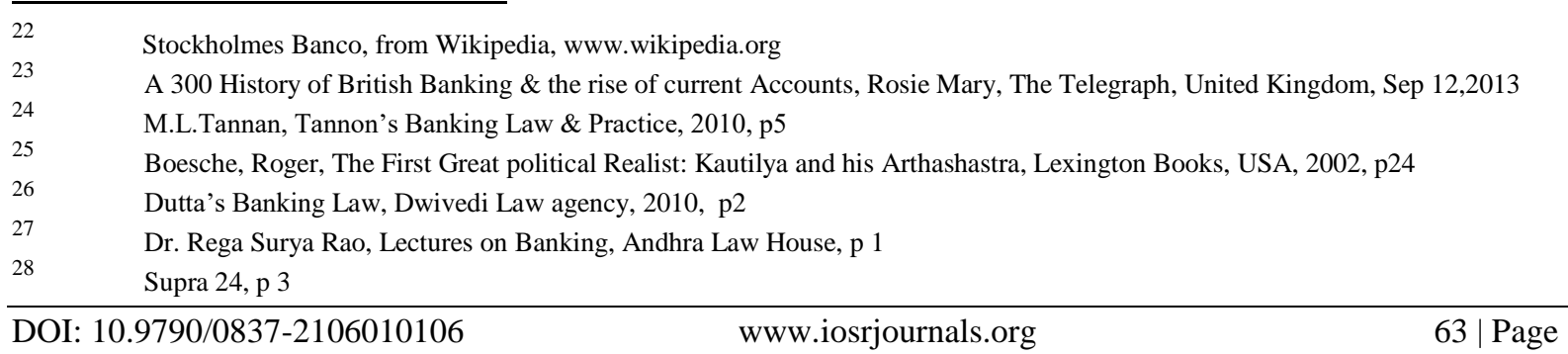


artificial scarcity of these siccas, by the sarafs. The Britishers in this era were at the mercy of Mughal merchants. Since on their arrival in India, they would require earnest money, which consequently forced them to deposit the bullions brought from their homeland till they could be minted into coins with the money lenders.

This ordeal would more often than not depreciate the value of their bullion. There was a deliberate delay in coin making to effect such situation \& favor the money dealers. However lending part of the banking business was carried out by 'seths' under the patronage of Mughals. These Seths made merry \& created huge estates out of this business. Noteworthy to point out that Mughals introduced the concept of Best Banker Awards, like in the case of Mulla Abdul Hai, who was conferred the title of Umdat-ul-Tujjar meaning the most eminent banker and Fateh Chand of Bengal, who was titled Jagat Seth, meaning the banker of the world by Mughal ruler Faruk Siyar. The merchants of Surat were so rich that Murad(brother of Aurangzeb) borrowed a huge sum of rupees ten million by issuing abond guaranteeing its repayment. However on his failure to win succession case against Aurangzeb, the debt remained unpaid. Imagine the courage of creditors who asked Aurangzeb to redeem this amount, who eventually conceded to the claim. However the creditors later took a u-turn by saying that they only wanted the acknowledgment of the debt and did not wish to get a single penny back \& the emperor could treat it as a gift. ${ }^{29}$ The modern Banking originated somewhere in last decades of $18^{\text {th }}$ century. During the British Rule, the erstwhile Presidency Banks were regulated under the Royal Charters \& East India Company at that time. The State Bank of India was established as early as 1806 as the Bank of Calcutta. It was then renamed as Bank of Bengal in 1809 as one of the three Presidency Banks. This commercial bank was believed to mainly fund General Wellesly's wars. ${ }^{30}$ This was followed by the Bank of Madras in July, 1843, as a joint stock company,through the reorganization and amalgamation of four banks viz., Madras Bank,Carnatic Bank, Bank of Madras and the Asiatic Bank. This bank brought about major innovations in banking such as use of joint stock exchange, conferring of limited liability on shareholders, acceptance of deposits from the general public, etc.

The Bank of Bombay, the last to be set under the British Raj pursuant to the charter of East India Company, was established in 1868, about a decade after India's first war of independence. ${ }^{31}$ Along with Bank of Bengal two other Presidency Banks, Bombay \& Madras were merged to form 'Imperial Bank of India' in 1921

which upon independence became the 'State Bank of India' in 1955. State Bank of India acted as quasi-central bank until the time RBI was established in 1935. The establishment of central banks during this period was the outcome of International Financial Conference held at Brussels in $1920 .^{32}$ The retrograde regulations were at the same time non extensive before the well settled law \& had all the roam for transgression \& non-compliance. Even though the Company law was already enacted by 1850 , yet at the time of Presidency banks, the law was not applicable to banking companies. A commission by the name 'Central Banking Enquiry committee' under the Chairmanship of Sir B.N Mitra was set up in 1929 to study the aspects \& reasons of failure of various banks. The committee submitted its report in 1931, which became a source of reform in the regulations \& control. Besides this the recommendations of Hilton Young Commission was instrumental in the enactment of the Reserve Bank of India Act, 1934. The establishment of Reserve Bank of India initially was seen to regulate monetary management, volume \& cost of Bank credit. However it was not before the enactment of a fullfledged Act, namely 'The Banking Companies Act,1949, which dealt exclusively with the banking regulation, in 1949 that all the major aspects of banking system came to be regulated. The Act was renamed as 'The Banking Regulation Act' from March 1966. The Act vested in RBI the responsibility relating to licensing of banks, branch expansion, liquidity of assets, management \& method of working. ${ }^{33}$ The current Indian banking sector is classified broadly into Scheduled \& Non Scheduled banks. The scheduled banks are those banks which are enumerated in the second schedule of RBI Act 1934, comprising of Scheduled commercial \& Scheduled cooperative Banks. The scheduled banks are further classifiable into the following 5:

1) State Bank of India \& its Associates

2) Nationalized Banks

3) Private Sector Banks

4) Foreign Sector Banks

5) Regional Rural Banks

The profile of SBI has seen a huge turnaround in the course of history \& is currently one of the largest banks in India. The bank is the best large sized bank of $2016^{34}$, with 2.93 lakh employees working in this institution as in 2016. The bank currently has 59000 ATMs spanned across the length \& breadth of the

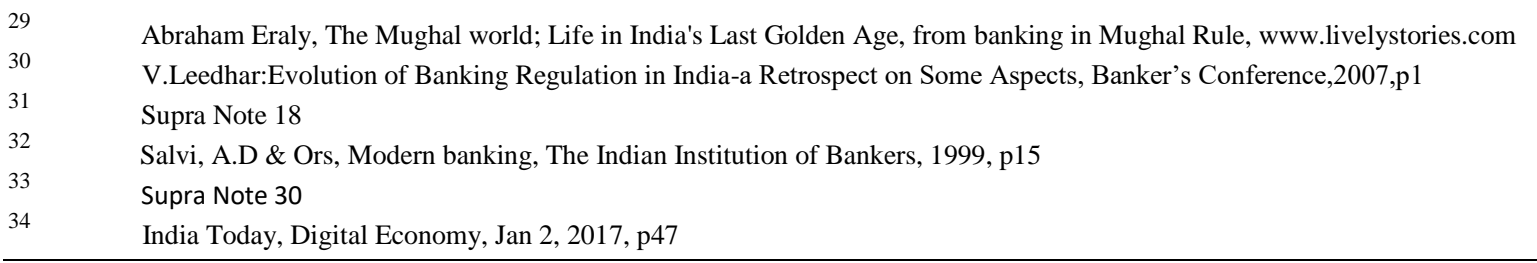

\begin{tabular}{|c|c|}
\hline DOI: $10.9790 / 0837-2106010106$ & www.iosriournals.org \\
\hline
\end{tabular}


country, with 23.30 crore debit cards \& a customer base of 30.12 crores. In the year 2016, alone, SBI processed 13 crore subsidy transactions \& trained over 750000 indifferent self employment ventures under the Mudra loan scheme. In many respects this institution has continued to remain an important player in the Indian economy, since its inception. In early 60s except SBI all other banks were owned \& operated by private persons. The government issued an ordinance 'Banking Companies (Acquisition and Transfer of undertakings) ordinance 1969 'and nationalized 14 largest banks with effect from the midnight of $19^{\text {th }}$ July 1969 .Noteworthy these banks contained $85 \%$ of bank deposits in the country. In the $2^{\text {nd }}$ round of Nationalization, 6 more commercial banks were nationalized, thus bringing the control of the government to about $91 \%$ on banking business. The Banking business in India is currently regulated by various enactments passed from time to time which provide for its definition, scope, \& control. The Banking Regulation Act, 1949 regulates all banking firms in India. Initially the law was applicable only to banking companies but in 1965 it was amended to include cooperative banks as well ${ }^{35}$.

As per the definition of section 5 clause (b), under the interpretation clause of the Banking Regulation Act, 1949 ,

"Banking" means accepting, for the purpose of lending or investment, of deposits of money from public, repayable

on demand or otherwise, and withdrawal by cheque, draft, order or otherwise.

As per this definition, Banks are primarily concerned with the receipt of money as a first \& foremost part of its business activity. This acceptance must not be misunderstood for gratuitous payments but this money is received in the course of a legal relationship created between the bank \& its clientele binding themselves. The bank in the course of this legally recognizable relation, accepts deposits made by customers usually in their respective bank accounts. This relationship is basically a relationship of trust, wherein the customer reposes full faith in the integrity of the legally recognized institution for the safe keeping \& security of his deposit. The money so deposited benefits the bank as well as the customer in equal measures. For the bank it forms the capital for the institution, while as for the customer besides the safety \& security of his funds, receives interest thereon which adds value to the deposited amount. The bank lends or advances money from the same pool of collected money in the form of loans, withdrawals etc. This advancing again creates a legally recognizable agreement wherein the loanee after accepting the conditions laid in the scheme, promises to return the same along with interest as per the time prescribed under the scheme. With the advent of economy, the role of banks has kept on increasing manifolds to accommodate the ever growing demand of society. Consequently banks \&financial institutions have attained paramount significance in influencing the lives. From the Indian standpoint, being a developing economy, the banking system is indispensible. The government utilizes the institution of banking to ameliorate the conditions of poor by providing subsidized agricultural loans to the farmers launching low interest loans like the DRI (Differential Rate of interest) for the low income groups, besides providing other financial services at the door steps of the people.

\section{IV. BANKING BUSSINESS \& ACTIVITY: A STATE RETROSPECT}

The banking business in Kashmir was not carried out in an organized manner. Due to the majority populace practicing the Islamic faith, the general perception was that interest-banking was un-Islamic, as Islam forbade usury or charging of Interest on loans. However the Islamic finance options weren't available to the masses, with literally no such established institution which could provide such facilities and during need they had no option but to avail the same through the means available. Since ancient periods the entire business was carried out by 'Munims' 'seths' 'suud-dar's or Money lenders, as was the case prevalent throughout India, who ruled the roost by charging exorbitant interest rates that most often than not left the person seeking such advance, bankrupt. And since the higher interest virtually broke the back of the borrower, the money remaining unpaid, the money lenders would in reciprocation for the debt, bond those people for life as slaves. In Kashmiri 'Suud'dar' or 'suud-khor', was used for people advancing loans for heavy interest rates. The terms literally meant 'Interest practisers', which has a negative \& strong connotation as against the 'money lenders' more close to an abuse. The negativity attached to this business was mainly religious in nature. Though during the transit period to modern day banking in Kashmir, some banks like the Grindlays Bank, National Bank \& Imperial Bank functioned in the state although to a limited extent. However due to illiteracy and ignorance, there was little access to these institutions. During this phase also the financial transactions was mainly carried out by the money lenders. In this era, the law didn't permit banks to hold mortgages against the lent advances, which made the institutions even more skeptical in lending, thus restricting lending to the affluent class only. Worthy to quote the saying of an American comedian, Bob Hope, "A bank will lend you money if you can prove you don't need it"

35

en.wikipedia.org/wiki/Banking_Regulation_Act 1949

DOI: 10.9790/0837-2106010106 www.iosrjournals.org $65 \mid$ Page 
Since this state of affairs continued for a long time consequently the miseries of common people remained unattended, with literally no development \&improvement in the living standards of people. The trade \& industry was at the lowest ebb \& was in need of a major overhaul. The fact prompted the then Maharaja of the state, Hari Singh to have some institution which could serve the people besides liberating them of the exploitation carried out by the moneylenders Admittedly the bank came into being through the 'Memorandum' initiated by the Finance and Development Minister of the state of Jammu \& Kashmir on19-06-1930. The preamble of the Memorandum read as, "In his keen anxiety to improve economic condition of his subjects, His Highness the Maharaja Hari singh, from time to time, gave verbal instructions to the under-signed to expedite the consideration of the proposal to establish a state Bank in the state. ${ }^{, 36}$ Managing Director of the Central Bank of India, Mr. Sorabji N Pochkanwala was instrumental in the establishment of this institution named The Jammu \& Kashmir Bank Ltd., On October 1, 1938. The bank started to function after receiving the certificate of commencement of business on July 4, 1939, as the first State owned bank of the country. As such the Maharaja laid the foundation stone of the Bank's branch building at Residency Road Srinagar on the same day. ${ }^{37}$ According to extended central laws of the state, J\&K Bank was defined as a government company as per the provisions of Company Act, $1956 .{ }^{38}$ Riding on the assistance \& efforts of eminent traders and manufacturers the first financial institution in the form of a bank was established in the state. The government appointed the first board of directors in 1938. The Jammu \& Kashmir Bank Ltd., with its authorized capital of Rs 50.00 lakhs, divided into Rs 2.00lakh shares of Rs 257 each. At the time of its incorporation State of J\&K held major $92 \%$ share, with private individuals Mr. Ab. Aziz Mantoo (a Srinagar based merchant), holding a total of 200 shares, Ab Hamid (a senior advocate, state councillor) held 200 shares, Whileas B.N Pestonjee, another prominent merchant held shares to the tune of 150.The Bank functions as a universal bank in Jammu \& Kashmir and as a specialized bank in the rest of the country. It is also the only private sector bank designated as RBI's agent for banking business of the central government, besides collecting central taxes for CBDT. The bank was incorporated in 1938, and is listed on the NSE and the BSE.

It has a track record of uninterrupted profits \& dividends for four decades. The J\&K Bank is rated P1+, indicating the highest degree of safety by standard \& poor and CRISIL. ${ }^{39}$ These facts suggest that Jammu \& Kashmir Bank over a period has ushered huge growth, thriving in a volatile \& sensitive state of J\&K. The bank has off late become the mainstay of growth for the state in particular by contributing hugely in the infrastructure, job creation, lending etc., in the state. The bank was founded on October 1, 1938 under letters patent issued by Maharaja Hari Singh, the then ruler. The Maharaja as discussed had invited eminent investors to become the founding directors \& shareholders of the bank. The notable among those were Pandit Sriniwas Mangotra, Abdul Aziz Mantoo, Pesten Jee, \& Bhagat family. The bank commenced its banking business on July 4, 1939 \& was considered the first of its nature \& composition as a state owned bank in the country. The bank was established as a Semi-government enterprise with participation in capital by state \& the public under the state government control. In year 1971, the bank had acquired the status of a scheduled bank and was declared as an "A" class bank by the Reserve Bank of India in $1976^{40}$. The bank had to face serious problems at the time of partition when out of its total 10 branches two branches of Muzaffarabad, Rawalkot \& Mirpur fell to the other side of border (now Pakistan Administered Kashmir) along with cash \& other valuable assets. The bank created history on December 8, 1995, when at the request of Union Bank of India, it took over its branch at Khaltsi in Ladakh with all its liabilities. It was remarkable in the sense that it was for the first time a private sector bank had taken over branch of a public sector bank. ${ }^{41}$ The bank celebrated its platinum jubilee in 2013 by achieving a net profit of Rs. 10.0 billion \& total business of Rs 1000billion. During the financial Year 2015-16, 40 new branches were opened taking the total number of branches to 857 as on 31-03-2016, spread over 20 states andone Union territory, with 462 Rural, 193 Urban, 157 Semi-urban and 45 Metro branches. ${ }^{42}$ Under the dynamic leadership of the recently appointed chairman, Mr. Parvaiz Ah, the institution aspires to scale new heights. Mr. Parvaiz Ahmad has alreadyinitiated a reform process, marshaling his resources to bring the bank back to glory \& rescue it from the recent slump the institution has been through. TheChairman being aware about the institution as a whole, having manned top positions in the institutional set up since early days of his illustrious career, has out of his experience started to plug the loop-holes, which existed for long. The focus under his reign has shifted back to financial health of the institution, without actually hampering the social initiatives the bank has been known for since long in the state of Jammu \& Kashmir, where such initiatives become even more necessary 
given the peculiar features it has. It is hoped that the approach of the current dispensation will yield dividends \& prove fruitful to all stake holders concerned.

\section{CONCUDING REMARKS}

Given the Indian societal setting, with the economy fragile, living standards below par, unaddressed hunger, social disparity, \& other cultural inhibitions that mark a stumbling block in its growth, the banking industry can be utilized as an instrument to engineer a social change, given its influence on almost all sectors of public life. This makes continual progressive reform in banking a dire need of the hour. In consonance to this thought the banking industry as discussed in the preceding paragraphs has been through a reform process, reviewed in order to overcome these challenges \& transitional hurdles coming in the way of smooth transformation. Despite all the poor indicators, India has made huge strides in the banking technology, trying to catch up fast with the ever growing \& competitive banking industry of the modern developed nations. The advancement in banking technology has been supported \& facilitated by the technology infrastructure \&administrative innovations for which the governmental dispensations at the Centre as well state level have been committed \& invested heartily, making every effort to ensure the country doesn't lag far behind in this aspect of prime importance in the global context. Especially with its 2.15 lakh ATM network \& mobile banking, it would misleadingly appear that much has been done in this direction. However peeping from another realistic prism all that glitters may not be gold.The factual account at this critical stage is that such facilities remain largely concentrated in Urban locations. Consider this between October 2013 \& October 2015alone, the number of ATMs increased around 43\%. But a stunning $80 \%$ of these ATMs are in metros, urban or semi-urban areas, making it all the more difficult for those in villages \& small towns to access them. ${ }^{43}$ The financial inclusion sloganeering as such has not seen its eventual success. Since rural areas need more of this inclusion given a plethora of disadvantages a village life suffers, ranging from lack of alternate avenues to lack of exposure, it becomes imperative to focus at grass root levels and connect these forsaken lands with technology $\&$ make this a friendly affair for all alike. Conversely the safety \& security regarding these ATMs has become one of the moot points in the recent past, which on \& off get looted despite so much of spending on surveillance and security. In Kashmir alone, an approximate 30.0 lakhs, have been looted from ATMs by armed men in a space of three months. In the state of J\&K, a total of 1006 ATMs ofJ\&K Bank, a major banker in the state, as on $31 / 03 / 2016$ span across the length $\&$ breadth of state, besides major Indian cities ${ }^{44}$. The bank in its initiative has beentrying to bring the whole population within its network \& has successful in doing so to an appreciable extent. However as mentioned, the burglaries taking placeevery now \& then ask for immediate attention. Be it the lapses in security \& surveillance, the difficult prevailing situation in the valley or non- meticulous use offunds spared for this purpose, the concern is grave. So while advocating the enlargement of ATM network in the hinterland, the aspect of safe keep of assets has notto be ignored \& a comprehensive security plan put in place to check such flagrant lapses. As per R.B.I data, Indians use 661.8 million debit cards \& 24.5 million credit cards as on March 2016. The government recently launched the e-wallet initiatives,impressing upon the citizens to use electronic or internet banking \& encouraged cashless transactions, post the demonetization period. However it is pertinent tonote that India being a developing country has not the required infrastructure \& means to hurriedly realize its goal of a cashless society. RBIs own estimates reveal that there are only 1.4 million POS (Point of sale) terminals in the country, out of which a significant number would be in large retail outlets. If this substantial number in large outlets is subtracted, then a meager five to 7 lakh POS terminals can't cater to a huge populace of a country like India. Additionally an inherent reluctance is shown by the common masses in using such modern ways of transacting business. As per a survey, $94 \%$ of the debit cards areused only for withdrawing money from the ATMs \& not for the electronic transactions of other kind. This reluctance may be attributed to many social \& economic factors that actually hinder the idea of going global \& going digital. There is a fear of fraud. The fear is justified on the count that recently a whopping 3.6 million cards of various banks including the oldest State Bank of India, were compromised \& in a state of shock, chaos \& emergency, such a huge number of cards were rendered withdrawn after a number of fraudulent cases were reported. Forget the common man, an IAS officer of Kashmir was recently victimized by internet fraudsters \& a substantial sum was siphoned out of his account ${ }^{45}$. Thus banking literacy \& awareness can be organized to augment such endeavors of positive change. Another major contributing factor which comes in the way of radical transformation is the internet accessibility. Lack of proper \& cheap means of internet access is still a dream in the developing part of the world. Noteworthy to mention here that the recent initiative of free internet access by Reliance Jio has done a world of good in this context. However it is facing stiff legal battles by other telecom

Annual Report, 2015-16, J\&K Bank, p 37

45 Peerzda Ashiq, Kashmir IAS topper victim of phishing, duped of Rs 75,000,Hindustan Times, 27 January 2013. 
operators in the country pursuing itto withdraw such freebies. As a matter of fact, nearly 850 million people in India are not connected through internet broadband. ${ }^{46}$ These stats may prompt a need of bringing about internet accessibility to masses on a war footing, if the digitization has to make a substantial breakthrough. Regardless of the tall claims of the politicians, an introspection may be needed to synchronize words with deeds \& do a fair amount of ground work before actually aspiring to achieve the desired goals. In other aspects of banking as well, there needs to be a comprehensive, consumer friendly and all inclusive plan to build upon the work already done to be commensurate with the modern day trends. The most crucial facet of banking industry is its human resource, which is instrumental in execution of all good ideas at the ground level. The workmen \& officers of the banks work tirelessly without complaining despite facing many difficulties. Extended work periods which usually don't carry a substantial additional remuneration seizes the initiative. The workmen \& officers need to be adequately compensated for extended hours of work. However if possible, the extended hours should be done away with \& not made a norm . As every human being for healthy growth \& development needs sufficient amount of rest. Overburdening not only has the effect on the health of the employee but also makes him less interested which consequentially brings out poor results. Health related complicacies due to work stress is quite common in bankers.. The labour laws need to be followed in letter \& spirit. Although RBI after receiving assent from the government in past has yielded to some the demands put forth by banking unions, wherein the $2^{\text {nd }} \& 4^{\text {th }}$ Saturday of every month are designated as bank holidays, but the bank associations have repeatedly requested for making banking business a 5 day per week affair. It is hoped that government may allow this concession given the stressful work of bankers. The provision will act as a much needed relief measure to the bankers, who could utilize these days for rejuvenation besides addressing their social \& family life. Since man is a social animal $\&$ he has no option but to socialize. As such the bankers need to be treated as humans not mere cobs in the machines. The modern trend asks for a collectivist as compared to individualistic well-being so as to serve the common good \& allow a bit of space to everyone who is anyone, and eventually realize the maximum happiness of the maximum number. Banking has to be in the same league aspiring to attain the same social good. In this context the recent purposive drive of facilitating the opening of small accounts 'Jan Dhan' would go a long way in financial inclusion besides measures like low interest \& hassle free loans like 'Mudra' to quote only one here, has benefitted largely to the small start-ups. Measures like these need to be continued even made more friendlier \& less technical. And in this direction banking law has to be further refined, reformed \& finetuned to not reduce it to a mere business activity but to seek the balancing of interests in a particular society between the individuals which it is composed of. Since in a welfare state law has to be an instrument of Justice. The law to cope with the ever-changing concept of justice has to live up to the aspiration of society. For that matter the law has to be dynamic. Prof C.K. Allen observes, "Experiment involves initiative \& a ceaselessly engineering law suggests picture of a science which is always seeking new instruments, new expedients, for new needs, in short, for good life. The picture is accurate enough for a great deal of what is called social legislation in the modern state, \& this is nowadays a preponderant part of law. It is true that today no enlightened system of law is constant with being merely static: it must also be dynamic, \& a great deal of thought \& knowledge is necessary in order to make it usefully dynamic. ${ }^{, 47}$ In this context, it is conclusively stated that all law including the law of banking needs to be guided by this philosophy. This shall eventually help the governmentnot only to achieve its avowed goals of modernism but will ensure an all inclusive growth \& development of the society. Thus regulations \& controls be not made abounty for few at the cost of the majority but as far as practicable be a win win situation for all!!! 
